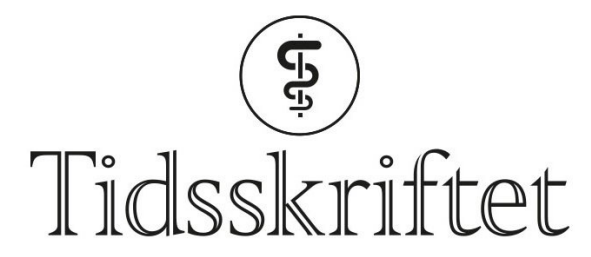

DEN NORSKE LEGEFORENING

\title{
Genetisk kreftscreening kan slå uheldig ut
}

FRA ANDRE TIDSSKRIFTER

KETIL SLAGSTAD

Institutt for helse og samfunn

Universitetet i Oslo

Det er knyttet stor forventning til polygen risikostratifisert kreftscreening, men undersøkelsene kan ha uheldige følger.

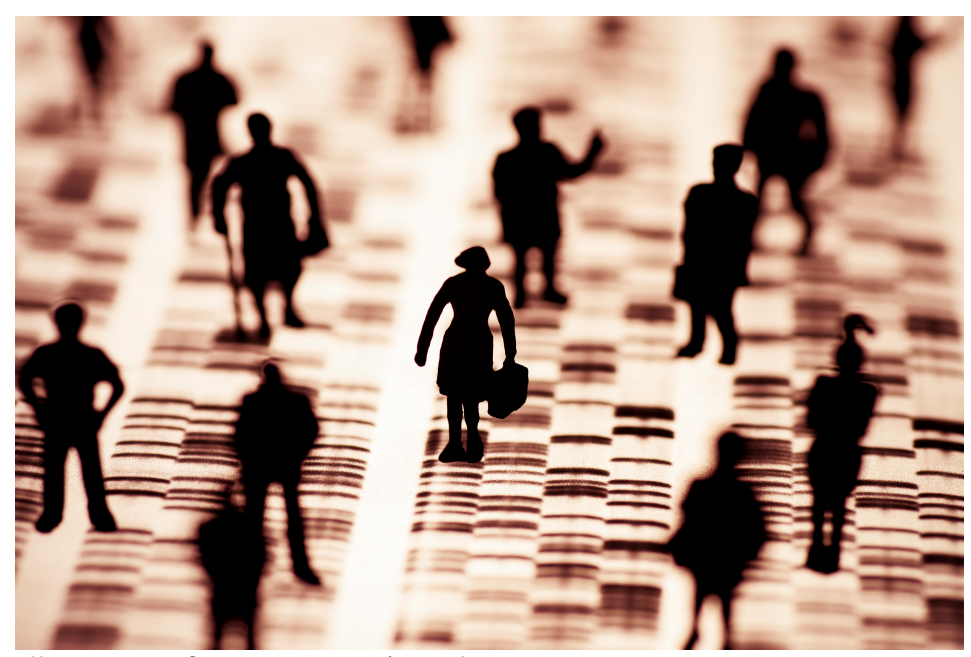

Illustrasjonsfoto: SusanneB/iStock

Persontilpasset medisin innebærer bl.a. å identifisere genvarianter som er assosiert med sykdom. Dette skjer ved hjelp av genomvide assosiasjonsstudier. Genvariantene kan så benyttes i screeningunders $\emptyset$ kelser for kreft, f.eks. for å unngå overdiagnostikk forbundet med tradisjonelle befolkningsbaserte screeningunders $\emptyset$ kelser. Slik polygen risikostratifisert kreftscreening forutsetter imidlertid innhenting av store mengder genetiske data fra befolkningen. Hvordan endrer denne forskningen hvordan vi tenker om risiko, sykdom og ansvar for å dele helsedata?

Forfatterne av en ny studie publisert i tidsskriftet Social Studies of Science forsøker å forstå denne utviklingen ved søk i Medline, forskningsrapporter, populærvitenskaplige artikler og blogger for perioden 2012-16 (1). Tekstene ble så gjenstand for koding og tematisk analyse gjennom en metode for databasert teoriutvikling.

Analysen viser at det er knyttet stort håp til hvordan polygen risikostratifisert kreftscreening kan revolusjonere kreftscreening gjennom mer målrettet screening, tidligere oppdagelse av kreft og lavere kostnad. Samtidig blir ulike aktører - leger, pasienter 
og befolkningen - ansvarliggjort på nye måter. Der tradisjonell screening gjøres på befolkningsnivå for å hjelpe den enkelte, forutsetter polygen risikostratifisert kreftscreening at befolkningen deler egne helsedata. Helsepersonell blir på sin side ansvarliggjort til å lære opp befolkningen i denne nytteverdien og å innhente dataene fra mange fagfelt. Gjennom såkalt dynamisk samtykke kan forskere innhente samtykke for bruk av data til nye formål, men slike samtykker kan også føre til at screeningdeltakerne blir ansvarliggjort for fremtidig bruk av slike data.

Forfatterne av studien peker på flere problemer ved polygen risikostratifisert kreftscreening som ikke vies nok oppmerksomhet i litteraturen. For det første kan personer med lav genetisk risiko bli rådet til mindre screening selv om sosioøkonomiske forhold taler for det motsatte. For det andre forutsetter screeningen at befolkningen har god kunnskap om og innsikt i konsekvensene av slik screening. For det tredje er det uklart hvordan helsepersonell skal få tid til å innhente alle de nødvendige data.

\section{LITTERATUR:}

1. Kerr A, Broer T, Ross E et al. Polygenic risk-stratified screening for cancer: Responsibilization in public health genomics. Soc Stud Sci 2019; 49: 605-26. [PubMed][CrossRef]

Publisert: 23. september 2019. Tidsskr Nor Legeforen. DOI: 10.4045/tidsskr.19.0476

(C) Tidsskrift for Den norske legeforening 2020. Lastet ned fra tidsskriftet.no 